\title{
Against Contextualism: Belief, Evidence, \& the Bank Cases
}

\author{
Logan Paul Gage
}

\begin{abstract}
Contextualism (the view that 'knowledge' and its variants are context-sensitive) has been supported in large part through appeal to intuitions about Keith DeRose's Bank Cases. Recently, however, the contextualist construal of these cases has come under fire from Kent Bach and Jennifer Nagel who question whether the Bank Case subject's confidence can remain constant in both low- and high-stakes cases. Having explained the Bank Cases and this challenge to them, I argue that DeRose has given a reasonable reply to this initial challenge. However, I proceed to argue that the current stalemate can be broken. Seeking to extend the Bach-Nagel critique, I offer a novel interpretation of the Bank Cases according to which the subject's evidence changes between low- and high-stakes cases. If I am correct, then, given the amount of support the Bank Cases have been thought to lend contextualism, the case for contextualism is seriously weakened.
\end{abstract}

Keywords: K. DeRose; K. Bach; J. Nagel; bank cases; contextualism; evidence.

Contextualism - the view that 'knowledge' and its variants are context-sensitivehas been supported, in large part, through appeal to intuitions about certain cases, especially the well-known Bank Cases of Keith DeRose. Recently, however, the contextualist construal of these cases has come under fire from invariantists who think that contextualists have stacked the deck in these cases. Having explained the Bank Cases, I will first note that DeRose has given plausible replies to some initial challenges to the argument for contextualism from these cases. Second, however, I will argue that there is yet another (closely related) reason to be skeptical that these cases support contextualism over its rivals; namely, DeRose and contextualists are wrong to think the subject's evidence has remained constant between Bank Case A and Bank Case B. If this is correct, then, given the amount of support the Bank Cases have been thought to lend contextualism, the case for contextualism is seriously weakened-for the stipulation that the subject's evidence remains constant is a key part of the contextualist's argument from such cases. I close with a consideration of some likely replies to my argument against contextualism.

\section{The Bank Cases}

For better or worse, epistemology has long been concerned with attempting to formulate a response to skepticism. In the 1990s, for instance, David Lewis, Keith Principia 17(1): 57-70 (2013).

Published by NEL - Epistemology and Logic Research Group, Federal University of Santa Catarina (UFSC), Brazil. 
DeRose and others suggested that the skeptic is engaged in subterfuge (Lewis 1996, p.556; DeRose 1995, p.6). The skeptic fools her interlocutor into proclaiming that he lacks knowledge, because 'knowledge' is a context-sensitive term. This view, known as contextualism, holds that the semantic value of even lexically identical knowledge-ascriptions can fluctuate between various contexts of utterance-much like 'I am President of the United States' takes on a different meaning, and a different truth value, when said by Barack Obama than when said by Joe Schmoe, because ' $\mathrm{I}$ ' is indexical. ${ }^{1}$ As Jason Stanley describes contextualism, it is "the semantic thesis that knowledge ascriptions, instances of ' $x$ knows that $p$ ', are context-sensitive in a distinctively epistemological way" (Stanley 2005, p.16). When a sentence is context-sensitive it can express different propositions when uttered in different contexts. According to most contextualists, in everyday contexts knowledge involves a rather low grade of justification, while in the philosophy classroom or other intellectually rigorous environments knowledge refers to something that requires a very high degree of justification. On this view, the skeptic wins by shifting the conversation to a more demanding context. This accounts for why her interlocutor readily acknowledges that he doesn't know there is an external world, or that he has hands, when pressed. But contextualists insist that the skeptic's victim can appropriately claim to know that there is an external world in other, more typical contexts. DeRose concludes, "To the extent that the skeptic does succeed, she does so only by raising the standards for knowledge, and so the success of her argument has no tendency to show that our ordinary claims to know are in any way defective" (DeRose 1995, p.6).

Contextualism is supported in no small measure because of its seeming ability to handle certain problematic cases-cases where knowledge apparently vanishes. The best-known of these cases are DeRose's Bank Cases:

Bank Case A. My wife and I are driving home on a Friday afternoon. We plan to stop at the bank on the way home to deposit our paychecks. But as we drive past the bank, we notice that the lines inside are very long, as they often are on Friday afternoons. Although we generally like to deposit our paychecks as soon as possible, it is not especially important in this case that they be deposited right away, so I suggest that we drive straight home and deposit our paychecks on Saturday morning. My wife says, "Maybe the bank won't be open tomorrow. Lots of banks are closed on Saturdays." I reply, "No, I know it'll be open. I was just there two weeks ago on Saturday. It's open until noon."

Bank Case B. My wife and I drive past the bank on a Friday afternoon, as in Case A, and notice the long lines. I again suggest that we deposit our paychecks on Saturday morning, explaining that I was at the bank on Saturday morning only two weeks ago and discovered that it was open until noon. But in this case, we have just written a very large and very important

Principia 17(1): 57-70 (2013). 
check. If our paychecks are not deposited into our checking account before Monday morning, the important check we wrote will bounce, leaving us in a very bad situation. And, of course, the bank is not open on Sunday. My wife reminds me of these facts. She then says, "Banks do change their hours. Do you know the bank will be open tomorrow?" Remaining as confident as I was before that the bank will be open then, still, I reply, "Well, no. I'd better go in and make sure." (DeRose 1992, p.913)

Contextualists like DeRose believe that what accounts for Keith's different response in Case B is that the context has shifted; higher justification is needed for Keith to know the high-stakes claim that the bank will be open. One way to think of this is that in Case A the word 'know' ranged over a limited domain in which somewhat-remote possibilities were properly ignored. Yet when the remote possibility that the bank has changed its hours in the last two weeks was raised to salience (Lewis 1996), Keith then appropriately denies that he knows the bank will be open on Saturday. Here, the word 'knows' ranges over an expanded domain. More possibilities are being considered.

By far, the biggest worry about contextualism's solution to Keith's differing knowledge ascriptions between cases A and B is that knowledge seems to vanish. This is a troubling consequence. Knowledge is valuable, and we don't want it appearing and disappearing depending on who we are talking to or where our conversation takes place. ${ }^{2}$ We want to be able to put our knowledge to work in practical reasoning, for instance, but this would be difficult if our knowledge kept disappearing. DeRose provides contextualists a good response to this concern, however: Knowledge of the standard, low-grade variety does not disappear in a high-stakes environment; nor does high-grade knowledge disappear in a high-stakes environment. As DeRose puts it, "What has ... [the subject] lost? What has gone away, been destroyed, been robbed from him? 'High' knowledge? No, he never had that. 'Low' knowledge? No, that he still has" (DeRose 2009, p.214). The Bank Case subject always lacked highgrade knowledge of the bank's hours and always retained low-grade knowledge of the bank's hours. This concern is thus unfounded.

\section{The Belief Challenge to Contextualism}

Recently, however, a more serious concern with contextualism-and specifically the case for contextualism from DeRose's Bank Cases-has arisen. To understand this worry, consider the structure of the argument from the Bank Cases to contextualism. Jeremy Fantl and Matthew McGrath helpfully render it as follows:

(1) What Keith says in uttering 'I know it'll be open tomorrow' in Bank Case $\mathrm{A}$ is true.

Principia 17(1): 57-70 (2013). 
(2) What Keith says in uttering 'No, I don't [know it will be open tomorrow]' in Bank Case B is true.

(3) Keith's epistemic position with respect to the proposition the bank will be open tomorrow is exactly as strong in Case A as it is in Case B.

(4) The best explanation of how all of (1)-(3) are true is that the content that the sentence 'Keith knows that the bank will be open tomorrow' has in the speech context Keith occupies in Case A is different from the content it has in the speech context Keith occupies in Case B.

So,

(5) The Bank Cases support contextualism over its rivals. (Fantl \& McGrath 2011, p.37-38)

Some epistemologists think premise (3) is false. If so, the case for contextualism from Bank Cases-a major source of support for contextualism-is undermined. Briefly consider two such epistemologists.

First, Kent Bach is skeptical that Keith can remain as confident of the fact that the bank will be open on Saturday in Case B as he was in Case A. If this is right, Keith lacks knowledge in the high-stakes case because he lacks belief (one component of his epistemic position) or at least an appropriate degree of belief, if belief comes in degrees. Bach refuses to "accept DeRose's stipulation regarding his high-standards version of his Bank case, according to which the attributor denies knowledge while 'remaining as confident as [he] was before that the bank will be open tomorrow' and yet concedes that he'd 'better go in and make sure'" (Bach 2005, p.76). Bach won't accept the stipulation because he thinks that one can be in a position to know but keep himself from knowing by thinking he is not in a position to know. Bach argues that since "attributing knowledge that $p$ requires believing that $\mathrm{p}$," the high stakes in Case B push up the confidence level Keith believes he needs for knowledge and thus make him think that he is not in a position to know (Bach 2005, p.78). ${ }^{3}$ In Case $B$, Keith has reservations about the bank being open on Saturday and thus reports his lack of knowledge. If this is so, the contextualist explanation of Keith's utterance in Case B is unnecessary. He says he doesn't know because he lacks confident belief, not because the semantic value of 'knowledge' has shifted between Cases A and B as contextualists insist.

Second, Jennifer Nagel likewise questions DeRose's stipulation that Keith retains the same credence in Case B as in Case A (Nagel 2008, p.279-94). ${ }^{4}$ Differences in stakes, she argues, often naturally lead to differences in confidence. Nagel thinks readers of Case $\mathrm{B}$, knowing that higher stakes tend to decrease confidence, naturally perceive Keith as "having unfounded confidence" (Nagel 2008, p.291). In other words, even if one grants DeRose's stipulation that Keith's belief remains just as it was in Case A, contextualism does not necessarily follow. If it is the case that the 
reader would expect Keith's confidence-level to drop, and it doesn't, the reader is likely to intuit that Keith does not know in Case B. Because his confidence does not drop, readers judge that "the character of [his] cognition is faulty" (Nagel 2008, p.292). Nagel concludes that truth-conducive factors rather than stakes/practical environment best account for readers' intuition that Keith lacks knowledge in Case B. If Bach and Nagel are right, no radical revision of our understanding of 'knowledge' along contextualist lines is necessary.

Yet DeRose is not without reply to the Bach-Nagel challenge. He differentiates between "stable" and "unstable" construals of confidence in the Bank Cases (DeRose 2009, p.190-93). An objector like Bach—one who sees it as psychologically implausible that Keith's credence remains the same in the high-stakes case-is utilizing the unstable conception of confidence. In this conception, our confidence that $p$ is often significantly reduced when facing high stakes: we seem less likely to act on $p$, and we are often disposed to deny that $p$ when asked. DeRose argues that it is just as reasonable-and even more natural-to see confidence in such cases in a "stable" way where confidence in high—stakes scenarios is not diminished. Keith's dispositions remain stable, in a certain sense, between the cases: the high-stakes subject still has the disposition to affirm $p$ if and when he is back in a low-stakes situation. In this sense his confidence is stable.

Some will doubt whether DeRose's (proposed) conditional disposition in the Bank Cases is really a disposition at all. C. B. Martin, utilizing Shope's conditional fallacy, has famously attacked conditional analyses of dispositions by pointing to so-called 'finkish' dispositions as counter-examples (Martin 1994). But to others, DeRose's reading of confidence is just as plausible as the unstable reading. No less than the likes of Quine and Ryle, after all, offered conditional analyses of dispositions (Quine 1960; Ryle 1963). And more recently, a number of philosophers-David Lewis among them-have defended conditional analyses of dispositions against finking and masking objections (Lewis 1997; Gundersen 2002; Choi 2008). Thus, these belief-related challenges to contextualism seem to end in a stalemate. Further, minds will differ as to whether it is (as DeRose thinks) usually the case that when a person returns from a high-stakes situation back to a low-stakes situation, she will still be likely to say she knows that $p$. Unlike DeRose, some will think that it is, in fact, typical for such a person to continue to deny $p$ even when she returns to a low-stakes context. Again, there seems to be a stalemate.

So what more can be said to those who find DeRose's stable construal of confidence in the Bank Cases plausible (e.g., those who find more sophisticated forms of conditional analyses of dispositions plausible)? In the following section, I'd like to consider a closely related alternative which accounts for the intuitions of Bach and Nagel and provides a plausible reason for a drop in Keith's credence level between Cases A and B. In this way we might adjudicate between the stable and unstable 
readings of confidence by providing reasons as to why the Bank Case subject's confidence should (or plausibly would) decrease.

\section{The Evidence Challenge to Contextualism}

As DeRose rightly points out, it is at least questionable whether Nagel is right to claim that stakes should cause a drop in the subject's confidence. What is far less controversial is that a decrease in one's evidence for a proposition $p$ should (at least typically $)^{5}$ cause a decrease in one's confidence that $p$. If this is right, we might bolster the Bach-Nagel position if we find that the evidential situation of the Bank Case subject has shifted for the worse between Cases A and B. In this section I will attempt to show that there is indeed a difference in the subject's evidential situation between Cases A and B; Keith has less evidence for the proposition that the bank is open in Case $\mathrm{B}$, all things considered. If this is right, it provides support for the Bach-Nagel construal of confidence in these cases, and thus greatly weakens the case for contextualism-for, if Keith's evidence that $p$ decreases, there is good reason to think his confidence that $p$ should also decrease.

We naturally tend to think of evidence as what we might call "courtroom evidence"-the knife seen in the suspect's hand; the candlestick found in the conservatory. But of course testimony (written or verbal) is a common source of evidence for propositions. In fact, if it were not, we'd arguably lack almost all justification for many ordinary claims. We'd know next to nothing about history, for example. But testimonial evidence need not be as direct as a historical account of, say, Tacitus or Toynbee. Testimonial evidence is often communicated very subtly. We constantly look for both verbal and non-verbal cues from others to gain information about our surroundings. If one walks into a supermarket only to see 100 people appearing scared, screaming loudly, and running frantically for the closest exit, one thereby has good evidence for the proposition that the supermarket is presently a dangerous place. We filter this information through our background knowledge: we know that bad things occasionally happen even in public places; we know that people do not usually look terrified for no reason; we know that while the worries of one person can easily be dismissed, it is highly unlikely that many people would be frantic for no reason (i.e., most people are reasonable). ${ }^{6}$

Now consider again the Bank Cases. In Bank Case A, Keith's wife presents the following testimonial evidence: "Maybe the bank won't be open tomorrow. Lots of banks are closed on Saturdays." Here Keith gains evidence that another intelligent and reasonable person believes that sometimes banks are closed on Saturdays. But he also knows that he was just there two weeks ago, and so he concludes that he knows the bank will be open on Saturday, all evidence considered. But his wife provides different evidence in Bank Case B:

Principia 17(1): 57-70 (2013). 
in this case, we have just written a very large and very important check. If our paychecks are not deposited into our checking account before Monday morning, the important check we wrote will bounce, leaving us in a very bad situation. And, of course, the bank is not open on Sunday. My wife reminds me of these facts. She then says, "Banks do change their hours. Do you know the bank will be open tomorrow"? (DeRose 1992, p.913, emphasis mine)

In Case B, Keith's wife explicitly reminds him of a litany of factors which create a high-stakes situation before asking him if he knows the bank will be open. Keith now has evidence that another reasonable person-perhaps the person he trusts most in the world-is very concerned that the bank will not be open on Saturday. ${ }^{7}$ Notice not only her specific reminders, but also the sub-text: when an interlocutor rehearses a litany of factors which could easily lead to bad consequences, we naturally take this as implying that they are concerned. In Case A, Keith gained evidence of no such deep-seated concern but only evidence that another person thinks it possible that the bank will be closed. By contrast, in Case B Keith receives evidence that his wife, another reasonable person, is greatly concerned that the bank will not actually be open on Saturday. Hence, Keith has evidence for the proposition, 'I should be concerned that the bank won't be open' in Case B but not Case A because he learns new information (viz., that a reasonable person whom he trusts is greatly concerned that the bank won't be open). ${ }^{8}$

This difference in evidence, I submit, accounts well for why Keith denies that he knows the bank will be open in Case B. He simply has new evidence. ${ }^{9}$ Moreover, this evidence-based model also accounts well for why Keith feels the need to check and see what the bank's hours are on Saturday. If the testimonial evidence presented by his wife is not the same between Cases A and B in the way I've suggested, then there is good reason to think that Keith's confidence in the proposition that 'I know the bank will be open Saturday' should/would decrease. ${ }^{10}$ Readers of the Bank Cases are likely to pick up on this and think Keith does not know in Case B. On this view, one might plausibly deny premise (3) of the argument for contextualism from the Bank Cases: Keith's epistemic situation has not remained constant, for his evidence is different in Cases A and B. A change in evidence is enough to undermine premise (3) all by itself. But it is worth emphasizing that this claim that Keith's evidence fluctuates between cases also accounts well for the Bach-Nagel intuition that it is implausible for Keith's belief to remain constant between the cases. After all, belief/confidence should typically track evidence.

\section{Objections}

But at this point it is worth considering what contextualists like DeRose might say in response to my evidentialist reading of the Bank Cases. First, the contextualist might 
ask, can't the cases simply be modified to avoid this worry that Keith's evidence (and therefore probably also his belief) has fluctuated between Cases A and B? Imagine that in both the low- and high-stakes cases, Keith pauses after seeing the long lines and considers all by himself the possibility that the bank will be closed on Saturday. ${ }^{11}$ In Case A, Keith says aloud to himself, "Maybe the bank won't be open tomorrow. Lots of banks are closed on Saturdays." Then he says, "No, I know it'll be open. I was just there two weeks ago on Saturday. It's open until noon." In Case B, Keith recalls the devastating consequences that will ensue if his check is not deposited and related facts. He then says to himself, "Banks do change their hours. Do I really know the bank will be open tomorrow?" Remaining as confident as he was before that the bank will be open, still, he answers himself, "Well, no. I'd better go in and make sure."

While it may at first appear counter-intuitive, even in such a revised scenario where Keith's wife is not feeding him additional evidence in Case B, Keith's evidential situation may well change between the cases. Earl Conee and others have suggested that evidence for propositions consists in mental states (or 'seeming states'). On Conee's view, "our evidence about the epistemic is how epistemic things seem to be" (Conee 2004, p.19). On this plausible view, one has prima facie reason to accept a proposition $p$ if $p$ seems compelling upon reflection (Conee 2004, p.15). ${ }^{12}$ Similarly, Michael Huemer advocates 'phenomenal conservatism,' the view that seemings that $p$ (of the sort Conee has in mind) provide prima facie justification for believing that $p$ in the absence of defeaters (Huemer 2011, p.46). ${ }^{13}$ The conscious seeming itself, on these views, is part of one's evidence. And why not, given that one is likely to think oneself every bit as reasonable as one's spouse? If this is right, then even in the revised Case B Keith arguably does not have the same evidence as in revised Case A, because he does not have the same mental state. In particular, in revised Case B he lacks the strong seeming that the bank will be open after some reflection. Hence even if we change the original Bank Cases in an attempt to save contextualism by imagining Keith talking to himself, it is still arguable that his evidence has not remained constant between Cases $\mathrm{A}$ and $\mathrm{B}$.

Second, even if my charge is admitted, and there is good reason to think there is an evidential shift between Bank Cases A and B, the contextualist might argue that this is a defect peculiar to the Bank Cases. After all, many similar cases have been offered in support of contextualism (and also in support of pragmatic encroachment). For instance, one might worry that Cohen's plane case and Fantl and McGrath's train cases present no such evidential shift between the high- and low-stakes cases. If so, these cases might still support contextualism-or at least preserve the stalemate between DeRose and his detractors urging what I have called the belief challenge to contextualism.

In response, I do not think the other cases fare any better against my evidence 
challenge to contextualism. In both the plane and train cases there is also an evidential shift. In Cohen's plane case, Mary (one of the interlocutors) raises a salient possibility of error-just like Keith's wife in the bank cases-and as such, is easily seen to convey concern about the accuracy of the flight itinerary: "Mary says, 'How reliable is that itinerary? It could contain a misprint. They could have changed the schedule at the last minute" (Cohen 1999, p.58). What else is Mary's interlocutor to think but that his companion Mary is raising what she takes to be a relevant possibility of error? Similarly, consider Fantl and McGrath's train cases. In the high-stakes version of this case the subject also raises relevant counter-possibilities: "That guy's information might be wrong. ... Maybe the ticket-seller misunderstood his question. Maybe he misunderstood the answer. Who knows when he bought the ticket?' " (Fantl \& McGrath 2002, p.67-8). Again, even though the subject raises these possibilities to herself, it is arguable that her evidence has changed. Hence in both of these other scenarios one can see an evidential shift akin to that in DeRose's Bank Cases.

Third and finally, Christoph Kelp suggests a potentially worrisome reply to my argument that a contextualist like DeRose might make. Kelp fears that I have only considered first-person accounts of the cases which are offered in support of contextualism. He notes that DeRose also discusses third-person cases which have the virtue of making clear that the subject's evidence remains constant. Because DeRose does not develop a specific third-person case, Kelp helpfully fills in some details:

Consider for instance Case A', a variation of Case A, in which the conversation is not between Keith and his wife but between A and B who are considering whether to call Keith to ask him about the bank. Here A may say, e.g.: "I remember that Keith went to check whether the bank is open on Saturdays only two weeks ago. Let's ask him. He knows whether it will be open tomorrow." Now contrast this with Case B', a variation of Case B, in which the conversation is between C and D. Suppose C says: "I remember that Keith went to check whether the bank is open on Saturdays only two weeks ago. Let's ask him." However, when D points out the importance of the question as well as the fact that banks sometimes change their opening hours, C admits: "You're right. Keith does not know whether the bank will be open tomorrow either." Since Keith is not part of either conversation and is, we may suppose, blissfully unaware of both, his epistemic position plausibly remains unchanged across the two cases. (Kelp 2013, p.3-4)

Kelp thus worries that the contextualist argument can be rescued even my point is conceded.

Kelp is right to note that I have only focused on first-person cases. In my argument against contextualism I thought it wise to begin with the most commonly cited argument for contextualism — the argument from first-person cases—which DeRose 
(2009, p.61, p.63) appears to think of as the strongest argument for contextualism. If I am right, contextualism is not the best explanation of the different knowledge attributions in the first-person cases. At this point there are other tools available to the invariantist (e.g., loose-talk or WAM), depending on their preferred standards for knowledge, to respond to the argument for contextualism from third-person cases. In the third-person case Kelp develops, high-standards invariantists might think that $\mathrm{C}$ and D wrongly attribute knowledge to Keith in the first case; his evidence simply isn't good enough for knowledge (or is at best a borderline case). Low-standards invariantists might think that $C$ and $D$ wrongly deny knowledge to Keith in the second case. Alternatively, one might grant that $\mathrm{C}$ and D's knowledge attributions are conversationally appropriate but still think them non-literal: Keith knows, but it is said that he doesn't because the attributors only mean to convey that Keith doesn't know any more than they do. ${ }^{14}$ The point of calling Keith in the first place was to attempt to gain new information. Saying that Keith doesn't know is a perfectly natural-if non-literal-way of conveying Keith's lack of new or useful information. With such replies readily available it is not at all clear that these third-person attributions are correct. Because of this, the argument to contextualism from such cases is of limited strength.

Perhaps the contextualist might argue at this point that contextualism's explanation is more parsimonious in that it covers both first- and third-person cases whereas I have called in at least two different mechanisms. But this would be a mistake. Parsimony is only an advantage if contextualism is actually the best explanation of both kinds of cases. But if my argument against first-person cases is correct-and even Kelp does not challenge my conclusion but only its scope-then contextualism is not the best explanation of the first-person cases.

It is difficult for many of us to hear the third-person attributions of Keith's knowledge as anything but incorrect. But for those to whom Kelp's cases sound perfectly natural, notice how crucial it is that the cases use two different pairs of attributors (viz., $\mathrm{A}$ and $\mathrm{B}$, and $\mathrm{C}$ and $\mathrm{D}$ ) on two different occasions. If contextualism is correct, however, it should not matter if the third-person case in question utilizes the same pair of attributors or if the attributors' stakes fluctuate within the same conversation. Consider, then, the following case to see whether contextualism is truly the best explanation of third-person cases.

An ordinary couple, A and B are driving home on a Friday afternoon. They plan to stop at the bank on the way home to deposit their paychecks. But as they drive past the bank, they notice that the lines inside are very long, as they often are on Friday afternoons. Although they generally like to deposit their paychecks as soon as possible, it is not especially important in this case that they be deposited right away, so B suggests that they drive straight home and deposit their paychecks on Saturday morning. A says to B, "I

Principia 17(1): 57-70 (2013). 
remember that Keith went to check whether the bank is open on Saturdays only two weeks ago. Let's call and ask him. He knows whether it will be open tomorrow." B agrees.

But just then, A receives a phone call from a surly woman at a collection agency. She claims that A is long overdue on his car payments. If their paychecks are not deposited into their joint checking account before Monday morning, his next car payment will not go through either, leaving them in a very bad situation. And, of course, the bank is not open on Sunday. Covering the phone with his hand, A whispers to B, "Scratch that. Keith doesn't know. After all, some banks close on Saturdays." But then the collector notices a glitch in her system. "Sorry, she says. I called the wrong number. It is someone else's car payment that is overdue." A hangs up and says to B, "Whew. Thank God. The collector got the name wrong. I guess Keith does know. Why don't you call him?" But before B can call Keith, B's phone rings. Upon answering it, B realizes that it must be the same surly collector. "Your car payment is overdue," she says to B. B in turn covers the phone and whispers to A, "Let's not call Keith. He doesn't know whether the bank will be open tomorrow. Banks do sometimes change their hours, you know." Upon learning about the phone conversation, A agrees that Keith doesn't know after all.

If DeRose has identified the correct features of a situation (viz., the standards of the attributors) which make knowledge attributions both appropriate and true, then this conversion should seem unproblematic. Recall that DeRose is after a semantic theory which actually captures the ordinary usage of 'knowledge' and its variants in our language (2009, p.47-79). I'd suggest, however, that while contextualism seems to imply it, ordinary speakers would never flip-flop in their knowledge attributions in this matter. Contextualism is not the best explanation of third-person cases.

If these objections to my argument fail and there is indeed good reason to believe that Keith's evidential situation has changed between the first-person bank cases, then the Bach-Nagel charge (i.e., that Keith's confidence in 'the bank will be open Saturday' will likely be diminished) seems well-supported. It does little good for DeRose to stipulate that Keith's confidence remains the same in both cases. His stable construal of confidence seems implausible if Keith's evidential position has changed. If Keith's evidential situation has indeed changed, then we have a good theory-neutral reason for thinking that the stable construal of confidence in such cases is mistaken.

\section{Conclusion}

Because the Bach-Nagel critique of contextualist interpretations of the Bank Cases ended in a stalemate, I have attempted to extend this critique. As I have argued, 
it is not merely that Keith does not know in Bank Case B because his confidence (his strength of belief) has dropped but that Keith's confidence has dropped because his evidential position has changed. Keith's confidence was lowered in Case B because his evidence for the proposition 'the bank will be open Saturday' diminished between Case A and Case B. If this is correct, the contextualist construal of the Bank Cases seems unwarranted-one need not speculate shifting semantic values for 'knowledge' but only that Keith's strength of epistemic position (construed along traditional lines) has changed between cases. ${ }^{15}$ If the change-in-evidence reading is even equally as plausible as the contextualist alternative, then, because it posits such a radical revision of our understanding of 'knowledge,' contextualism is not the best explanation of the Bank Cases. Thus, given the amount of support contextualists have claimed to derive from the Bank Cases, the case for contextualism appears significantly weakened in the face of this competing hypothesis. ${ }^{16}$

\section{References}

Bach, K. 2005. The Emperor's New "Knows." In: G. Preyer; G. Peter (eds.) Contextualism in Philosophy: Knowledge, Meaning, and Truth. New York: Oxford University Press.

Choi, S. 2008. Dispositional Properties and Counterfactual Conditionals. Mind 117: 795841.

Cohen, S. 1999. Contextualism, Skepticism, and the Structure of Reasons. Philosophical Perspectives 13: $57-89$.

Conee, E. 2004. First Things First. In: E. Conee; R. Feldman (eds.) Evidentialism: Essays in Epistemology. New York: Oxford University Press.

DeRose, K. 1992. Contextualism and Knowledge Attributions. Philosophy and Phenomenological Research 52: 913-29.

- 1995. Solving the Skeptical Problem. The Philosophical Review 104: 1-52.

. 2009. The Case for Contextualism. New York: Oxford University Press.

Dougherty, T. 2012. Pragmatic Encroachment and the Old Bank Cases: An Evidentialist Perspective. To appear. p.1-13.

Fantl, J.; M. McGrath. 2002. Evidence, Pragmatics, and Justification. The Philosophical Review 111: 67-94.

- 2011. Knowledge in an Uncertain World. New York: Oxford University Press.

Gage, L. P. 2014. Evidence and What We Make of It. Southwest Philosophy Review 30(2).

Gundersen, L. 2002. In Defence of the Conditional Account of Dispositions. Synthese 130: 389-411.

Huemer, M. 2011. Epistemological Egoism and Agent-Centered Norms. In: T. Dougherty (ed.) Evidentialism and Its Discontents. New York: Oxford University Press.

Kelp, C. 2013. Against Contextualism: Response to Gage. To appear. p.1-5.

Kvanvig, J. L. 2007. The Value of Knowledge and the Pursuit of Understanding. New York: Cambridge University Press.

Lewis, D. 1996. Elusive Knowledge. Australasian Journal of Philosophy 74: 549-67.

- 1997. Finkish Dispositions. The Philosophical Quarterly 47: 143-58.

Principia 17(1): 57-70 (2013). 
Martin, C. B. 1994. Dispositions and Conditionals. The Philosophical Quarterly 44: 1-8.

Nagel, J. 2008. Knowledge Ascriptions and the Psychological Consequences of Changing Stakes. Australasian Journal of Philosophy 86: 279-94.

Quine, W.V.O. 1960. Word and Object. Cambridge, MA: MIT Press.

Ryle, G. 1963. The Concept of Mind. London: Penguin.

Stanley, J. 2005. Knowledge and Practical Interests. New York: Oxford University Press.

Stapleford, S. 2012. Epistemic Duties and Failure to Understand One's Evidence. Principia 16: $147-77$.

Zagzebski, L. 2012. Epistemic Authority: A Theory of Trust, Authority, and Autonomy in Belief. New York: Oxford University Press.

Logan PaUl Gage Department of Philosophy

Baylor University

USA

logan_gage@baylor.edu

Resumo. O contextualismo (a concepção de que 'conhecimento' e suas variantes são sensíveis ao contexto) tem sido defendido em grande medida apelando-se para intuições sobre os Casos do Banco, de Keith DeRose. Recentemente, todavia, a construção contextualista desses casos tem sofrido ataques de Kent Bach e Jennifer Nagel, que questionam se a confiança dos sujeitos de Casos de Banco podem permanecer constantes tanto em casos de baixo quanto de alto risco. Tendo explicado os Casos de Banco e este desafio a eles, argumento que DeRose deu uma resposta razoável para este desafio inicial. Todavia, argumento que o impasse pode ser quebrado. Buscando extender a crítica de Bach-Nagel, ofereço uma nova interpretação dos Casos de Banco de acordo com a qual as evidências do sujeito mudam entre os casos de alto risco e de baixo risco. Se estou correto, então, dado o suporte que os Casos de Banco supostamente fornecem ao contextualismo, o caso em favor do contextualismo é seriamente enfraquecido.

Palavras-chave: K. DeRose; K. Bach; J. Nagel; casos de banco; contextualismo; evidência.

\section{Notes}

${ }^{1}$ More carefully, “... according to the contextualist, one speaker can truthfully say ' $S$ knows that $p$ ', while another speaker, in a different context where higher standards are in place, can truthfully say ' $S$ doesn't know that $p$ ', though both speakers are talking about the same $S$ and the same $p$ at the same time" (DeRose 2009, p.6).

2 There is not always agreement, however, as to why knowledge is valuable or exactly how valuable it is. See Kvanvig 2007.

${ }^{3}$ On Bach's account, moderate invariantists may think that Keith knows in both cases, for Keith wrongly thinks that he needs a higher degree of confidence.

${ }^{4}$ Nagel uses a version of the Bank Cases which substitutes 'Hannah' for 'Keith'. For clarity and consistency, I have retained Keith as the subject of the cases.

Principia 17(1): 57-70 (2013). 
${ }^{5}$ Perhaps there may be cases where belief should not necessarily be proportioned to evidence. However, it seems relatively uncontroversial that there should generally be a correlation between degree of belief and strength of evidence. For a recent defense of the claim that there is an epistemic duty to proportion belief to possessed evidence, see Stapleford (2012). ${ }^{6}$ When I say that we filter this information through our background knowledge, I do not mean to imply that this is necessarily an inferential process of perception. I have argued elsewhere that if we accept the phenomenal conception of evidence then background knowledge often affects which perceptions we have as evidence (Gage 2014).

${ }^{7}$ Interestingly, Zagzebski argues that, if we trust ourselves, epistemic trust in others (to the same degree as we trust ourselves) is rationally inescapable unless we accept a form of ethical egoism. Self-trust gives us a prima facie reason to trust others as much as ourselves. See chapter three of Zagzebski (2012).

${ }^{8}$ Christoph Kelp (2013) has also pointed out to me that there is another subtle difference in Keith's evidence between the cases. Namely, in Case A Keith's wife only mentions that many banks are closed on Saturdays, whereas the error possibility she raises in Case B is that banks sometimes change their opening hours. I suppose that DeRose could simply modify his cases to make them more consistent. But as Kelp points out, this difference could prove important due to the fact that Keith's initial evidence (i.e., that he was at the bank on a Saturday two weeks ago) is strong evidence against the actuality of the first counter-possibility but not the second.

${ }^{9}$ This view has the additional benefit that the moderate invariantist does not have to claim that Keith speaks falsely in Case B. Keith has a diminished strength of epistemic position in Case B; so it seems likely he really does not know in Case B.

${ }^{10}$ Intuitions will vary on how strong Keith's wife's testimonial evidence is for this proposition. But, given that Keith's spouse may well be the person he trusts most in the entire world, this is arguably strong evidence for Keith.

11 Thanks to Blake McAllister for suggesting this objection.

${ }^{12}$ Conee has in mind strong seemings/convictions, not whimsical feelings/beliefs (2004, p.15).

${ }^{13}$ Conee much prefers talk of "epistemic reasons" to Huemer's notion of "justification" (2004, p.15-6ff).

14 On this sort of strategy, see Dougherty (2012).

${ }^{15}$ It is worth noting that pragmatic encroachers like Fantl and McGrath also have a significant stake in DeRose's stipulation that Keith's epistemic position remains the same between Cases A and B. Pragmatic encroachment will also be undermined to some degree if my argument is sound.

${ }^{16}$ Many thanks to Jonathan Kvanvig, Blake McAllister, and an anonymous referee for helpful comments on earlier drafts. Thanks are also due to Christoph Kelp for his insightful comments at the 2013 Pacific Division meeting of the American Philosophical Association.

Principia 17(1): 57-70 (2013). 